\title{
Fast-growing chickens fed with lucerne protein-xanthophyll concentrate: growth performance, slaughter yield and bone quality
}

\author{
K. Kwiatkowska, M. Kwiecień ${ }^{1}$ and A. Winiarska-Mieczan \\ University of Life Sciences in Lublin, Institute of Animal Nutrition and Bromatology \\ Akademicka 13, 20-950 Lublin, Poland
}

KEY WORDS: lucerne concentrate, bone quality, carcass, broiler chickens

Received: 18 November 2016

Revised: $\quad 30$ March 2017

Accepted: $\quad 15$ May 2017

${ }^{1}$ Corresponding author:

e-mail: malgorzata.kwiecien@up.lublin.pl

\begin{abstract}
The aim of this study was to determine the effect of addition of lucerne protein-xanthophyll concentrate (LPC) on physicochemical, morphometric and strength characteristics of bone tissue as well as growth performance and selected slaughter parameters in broiler chickens. One hundred fifty broilers were assigned to three treatment groups, each group was replicated five times (10 birds in each). The control group (C) was fed a standard feed mixture without the experimental additive. The soyabean meal in the experimental diets was replaced with LPC in an amount of $1.5 \%$ (group 1.5\% LPC) or $3.0 \%$ (group $3 \%$ LPC). In comparison with group C, the LPC doses increased chicken body weight on day 21 of rearing, reduced the mortality rate by $50 \%$, increased pectoral muscle weight and reduced the content of abdominal fat by $42.5 \%$ and $51.5 \%$, respectively. Addition of $3 \%$ of LPC increased the chilled carcass weight by $13.2 \%$ and slaughter yield by $2.98 \%$, as compared with group C. The greatest length and the largest circumference of tibia and the highest values of the secondary moment of inertia (Ix) and mean relative wall thickness (MRWT) of femur and tibia were noted in the LPC-treated chickens. The obtained results indicate that the LPC supplementation enhanced bone mechanical strength resulting from the increase in the geometric parameters (Ix and MRWT) as well as the cortical layer thickness. The bones were characterized by higher flexibility and breaking strength. The increased content of $\mathrm{Ca}$ and $\mathrm{Zn}$ and the higher value of the bone density index indicate normal bone mineralization.
\end{abstract}

\section{Introduction}

Genetic progress in broiler chicken breeding increases the profitability of this branch of agricultural production on the one hand. On the other hand, imbalance and mis-synchronization in the growth of bird's anatomical parts can be observed. This leads to development of many skeletal diseases and abnormalities (Dibner et al., 2007). The causes of bone disorders in broiler chickens are usually complex, but the problem can be alleviated by appropriate nutrition.

Among various chicken feeds, soyabean meal is the major source of protein (Hammershøj and Steenfeldt, 2005). Due to the limitations imposed on genetically modified (GM) feeds, alternative sources of protein components supplied to feed are being searched. Lucerne protein concentrate (LPC) can 
be one of the alternatives to the expensive soyabean and it's GM version (Grela et al., 2013). LPC contains about $55 \%$ of crude protein, which is rich in exogenous amino acids. It is also a source of natural antioxidants (xanthophyll and its derivatives), vitamins (A, $\left.\mathrm{B}_{1}, \mathrm{~B}_{6}, \mathrm{~B}_{12}, \mathrm{C}, \mathrm{E}, \mathrm{K}\right)$, minerals (mainly $\mathrm{Fe}$ and $\mathrm{Cu}$ ), and saturated $(\mathrm{C} 16: 0)$, monounsaturated $(\mathrm{C} 16: 1, \mathrm{C} 18: 1)$ and polyunsaturated $\left(\mathrm{C} 18: 2_{\mathrm{n}-\mathrm{6}^{6}}\right.$ C18:3 ${ }_{n-3}$ ) fatty acids (Grela et al., 2013).

As a feed additive, LPC exerts a positive effect on the animal organism. Addition of LPC to animal diet was reported to enhance growth performance, increase feed efficiency, and improve the quality of meat and eggs (Karwowska et al., 2010; Krauze and Grela, 2010; Grela et al., 2014).

In the study conducted by Güçlu et al. (2004) on quails, addition of 3, 6 and $9 \%$ of lucerne to the diet had no significant effect on body weight, the feed intake and feed conversion ratio. Administration of lucerne in combination with ryegrass in the diet for laying hens reduced weight gain and feed intake (Mourão et al., 2006). As shown by Dong et al. (2007), addition of lucerne extract (Polysavon) reduced the accumulation of abdominal fat but exerted no effect on chicken performance. In investigations performed on growing turkeys, the highest weight gain and the lowest feed intake were found at addition of $3 \%$ of LPC, and the lucerne preparation reduced the number of bird deaths in the experimental groups (Krauze and Grela, 2010). In ducks fed lucerne-supplemented diet $(3,6$ and 9\%), there were no differences in the body weight, average daily gains, mortality rate and feed intake compared with the control group (Jiang et al., 2012). Partial replacement of soyabean meal with lucerne in laying hen nutrition did not have adverse effects on production traits (Laudadio et al., 2014). There are only a few studies indicating a possible effect of lucerne addition on bone formation processes, which are essential for animal welfare (Y1ldiz and Alpay, 2008). Furthermore, it has been found that polyunsaturated fatty acids can have an effect on the skeletal system, in both humans and animals, but the effect is not entirely clear (Shen et al., 2006). The available literature does not provide data on the effect of LPC on bone quality in broiler chickens. Therefore, we hypothesized that the addition of the lucerne concentrate to feed mixtures can complement and balance the nutritional composition of the feed, thereby contributing not only to improvement of growth performance but also to enhancement of $\mathrm{Ca}$ and $\mathrm{P}$ absorption, which may have a beneficial effect on the physicochemical and bone strength parameters.

Hence, the aim of the study was to determine the impact of LPC on the physicochemical, morpho- metric and strength of broiler bones and on the production yields and slaughter yield parameters.

\section{Material and methods}

All procedures applied during the research were approved by the Local Ethics Committee for Animal Testing at the University of Life Sciences in Lublin (Poland; Resolution No. 4/2009 of $20^{\text {th }}$ January 2009). The chickens were maintained in an animal house according to the guidelines of the Committee. The experiment complied with the Guiding Principles for Research Involving Animals.

\section{Experimental design, birds and diets}

In total, 150 1-day-old Ross 308 male broiler chicks with an average initial weight of $37.9 \pm 2.73 \mathrm{~g}$ (mean \pm standard deviation, SD) were used. The experiment was conducted over 42 days. The birds were weighed individually at the beginning of the experiment and labelled with wing tags on day 1 of rearing. The chickens were reared in cages located in a room with controlled temperature and humidity. Throughout the experiment, the 24-h lighting was provided. In the first week, the chickens were kept at a temperature of $33{ }^{\circ} \mathrm{C}$, which was then lowered stepwise by $2{ }^{\circ} \mathrm{C}$ at 1 -week intervals to the final value of $24^{\circ} \mathrm{C}$.

In the study, a 3-phase feeding programme was carried out: starter from day 1 to 21 , grower from day 22 to 35 and finisher from day 36 to 42 (Table 1). The grower and finisher mixtures were administered in the form of pellets, while the starter mixture was in the crumble form. The chickens were randomly allotted to three dietary treatments, each treatment was replicated five times (10 birds in each). The control group (C) was fed according to the NRC requirements (1994). The experimental groups were fed mixtures supplemented with $1.5 \%$ and $3 \%$ of LPC produced by Desialis-France Luzerne (Désialis, Châlons-en-Champagne, France) (Grela et al., 2013), which replaced soyabean meal (Table 2). From day 1 to 42 of age, all the chickens had ad libitum access to water and feed.

\section{Sampling and measurements}

During the experiment, the chickens were weighed on day 10,21, 35 and 42 of rearing. The feed intake and mortality were monitored, which allowed determination of the index of feed intake (FI) and the feed conversion ratio (FCR). On day 42, 10 representative chickens per group were selected according to the average weight. Before the slaughter, the birds were subjected to a 8 -h fasting 
Table 1. Ingredients and nutrient contents in feed mixtures according to feeding phases, $\%$

\begin{tabular}{|c|c|c|c|c|c|c|c|c|c|}
\hline \multirow{3}{*}{ Indices } & \multicolumn{3}{|c|}{ Starter (1-21 days) } & \multicolumn{3}{|c|}{ Grower (22-35 days) } & \multicolumn{3}{|c|}{ Finisher (36-42 days) } \\
\hline & \multirow{2}{*}{$\mathrm{C}^{1}$} & $1.5 \%$ & $3.0 \%$ & \multirow{2}{*}{ C } & $1.5 \%$ & $3.0 \%$ & \multirow{2}{*}{ C } & $1.5 \%$ & $3.0 \%$ \\
\hline & & \multicolumn{2}{|c|}{$\mathrm{LPC}^{2}$} & & \multicolumn{2}{|c|}{ LPC } & & \multicolumn{2}{|c|}{ LPC } \\
\hline Ingredients & & & & & & & & \\
\hline maize & 24.7 & 24.7 & 24.7 & 30.0 & 30.0 & 30.0 & 30.0 & 30.0 & 30.0 \\
\hline wheat & 42.7 & 42.7 & 42.7 & 35.9 & 35.9 & 35.9 & 36.8 & 36.8 & 36.8 \\
\hline soyabean meal $(46 \% \mathrm{CP})$ & 25.0 & 23.5 & 22.0 & 26.5 & 25.0 & 23.5 & 25.7 & 24.2 & 22.7 \\
\hline soyabean oil & 2.5 & 2.5 & 2.5 & 4.0 & 4.0 & 4.0 & 4.5 & 4.5 & 4.5 \\
\hline monocalcium phosphate & 0.86 & 0.86 & 0.86 & 0.9 & 0.9 & 0.9 & 0.72 & 0.72 & 0.72 \\
\hline limestone & 1.4 & 1.4 & 1.4 & 1.1 & 1.1 & 1.1 & 0.93 & 0.93 & 0.93 \\
\hline sodium bicarbonate & 0.08 & 0.08 & 0.08 & 0.8 & 0.08 & 0.08 & 0.05 & 0.05 & 0.05 \\
\hline $\mathrm{NaCl}$ & 0.29 & 0.29 & 0.29 & 0.25 & 0.25 & 0.25 & 0.25 & 0.25 & 0.25 \\
\hline vitamin-mineral premix ${ }^{3}$ & 0.25 & 0.25 & 0.25 & 0.25 & 0.25 & 0.25 & 0.25 & 0.25 & 0.25 \\
\hline fat-protein concentrate ${ }^{4}$ & 1.0 & 1.0 & 1.0 & - & - & - & & - & - \\
\hline choline chloride & 0.08 & 0.08 & 0.08 & 0.07 & 0.07 & 0.07 & 0.04 & 0.04 & 0.04 \\
\hline DL-methionine 99\% & 0.30 & 0.30 & 0.30 & 0.22 & 0.22 & 0.22 & 0.20 & 0.20 & 0.20 \\
\hline L-lysine $\mathrm{HCl}$ & 0.36 & 0.36 & 0.36 & 0.25 & 0.25 & 0.25 & 0.21 & 0.21 & 0.21 \\
\hline L-threonine $99 \%$ & 0.18 & 0.18 & 0.18 & 0.06 & 0.06 & 0.06 & 0.05 & 0.05 & 0.05 \\
\hline Calprona PL (acidifier) & 0.3 & 0.3 & 0.3 & 0.4 & 0.4 & 0.4 & 0.4 & 0.4 & 0.4 \\
\hline LPC & - & 1.5 & 3.0 & - & 1.5 & 3.0 & - & 1.5 & 3.0 \\
\hline \multicolumn{10}{|l|}{ Nutrient content } \\
\hline $\mathrm{ME}, \mathrm{MJ} / \mathrm{kg}^{5}$ & 12.66 & 12.51 & 12.34 & 13.02 & 13.05 & 13.00 & 13.15 & 13.17 & 13.13 \\
\hline crude protein, $\%{ }^{6}$ & 20.10 & 19.77 & 19.34 & 19.03 & 19.07 & 19.04 & 18.29 & 18.31 & 17.86 \\
\hline crude fibre, $\%{ }^{6}$ & 3.05 & 3.01 & 2.96 & 2.93 & 2.96 & 2.91 & 2.98 & 2.96 & 2.90 \\
\hline lysine, $\%^{6}$ & 1.29 & 1.27 & 1.25 & 1.10 & 1.11 & 1.09 & 1.05 & 1.06 & 1.04 \\
\hline methionine, $\%{ }^{6}$ & 0.59 & 0.59 & 0.58 & 0.49 & 0.50 & 0.49 & 0.46 & 0.47 & 0.47 \\
\hline methionine + cystine,$\%^{6}$ & 0.93 & 0.92 & 0.91 & 0.81 & 0.81 & 0.80 & 0.78 & 0.79 & 0.78 \\
\hline tryptophan, $\%$ & 0.23 & 0.23 & 0.22 & 0.20 & 0.21 & 0.21 & 0.20 & 0.21 & 0.21 \\
\hline arginine, $\%{ }^{6}$ & 1.27 & 1.24 & 1.21 & 1.18 & 1.19 & 1.16 & 1.16 & 1.17 & 1.14 \\
\hline $\mathrm{Ca}, \%{ }^{6}$ & 0.88 & 0.87 & 0.89 & 0.94 & 0.95 & 0.89 & 0.82 & 0.83 & 0.81 \\
\hline $\mathrm{P}$ available, $\%^{5}$ & 0.42 & 0.41 & 0.41 & 0.49 & 0.48 & 0.41 & 0.37 & 0.38 & 0.38 \\
\hline total $P, \%{ }^{6}$ & 0.67 & 0.66 & 0.65 & 0.64 & 0.66 & 0.65 & 0.61 & 0.62 & 0.61 \\
\hline $\mathrm{Na}, \%{ }^{6}$ & 0.15 & 0.16 & 0.16 & 0.13 & 0.14 & 0.14 & 0.13 & 0.14 & 0.14 \\
\hline $\mathrm{Zn}, \mathrm{mg}^{6}$ & 49.1 & 49.2 & 49.4 & 49.5 & 49.6 & 49.3 & 49.8 & 49.5 & 49.7 \\
\hline $\mathrm{Fe}, \mathrm{mg}^{6}$ & 89.9 & 90.4 & 90.8 & 59.9 & 60.2 & 60.5 & 59.8 & 60.4 & 60.2 \\
\hline $\mathrm{Cu}, \mathrm{mg}^{6}$ & 18.8 & 19.2 & 19.4 & 18.8 & 18.2 & 18.1 & 18.9 & 18.1 & 18.3 \\
\hline
\end{tabular}

${ }^{1} \mathrm{C}$ - control; ${ }^{2} \mathrm{LPC}$ - lucerne protein concentrate; ${ }^{3}$ provided per $\mathrm{kg}$ feed (for feeding periods 1-21, 22-35 and $36-42$ days, respectively): UI: vit. A $15000,12000,12000$, vit. $D_{3} 5000,5000,5000$; mg: vit. $E 75,50,50$, vit. $K_{3} 4,3$, 2, vit. $B_{1} 3,2$, 2, vit. $B_{2} 8,6,5$, vit. $B_{6} 5,4,3$, biotin 0.2, 0.2, 0.05, folic acid 2, 1.75, 1.5, nicotic acid 60, 60, 60, pantothenic acid 18, 18, 18, choline 1800, 1600,1600 , Mn 100, 100, 100, I 1, 1, 1, Zn 100, 100, 100, Fe 40, 40, 40, Cu 16, 16, 16, Se 0.15, 0.15, 0.15; $\mu \mathrm{g}$ : vit. $\mathrm{B}_{12} 0.016,0.016,0.011 ;{ }^{4} \mathrm{~kg}$ of protein-fat concentrate contained: $39 \%$ crude protein, $2 \%$ crude fat, $10.8 \mathrm{MJ} \mathrm{ME;}{ }^{5}$ calculated values: ME - calculated according to European Table of Energy Values for Poultry Feedstuffs (Janssen, 1989) as sum of metabolizable energy content of components; ${ }^{6}$ analysed values

(with unlimited access to water). The slaughter and post-slaughter processing of the chickens from all the experimental groups was carried out in the same specified technological conditions. On the slaughter day, the chickens were weighed to determine the pre-slaughter weight. The slaughter was performed by a person authorized to slaughter experimental animals. The slaughter involved stunning, which causes rapid and persistent loss of sensation and perception, followed by intersection of blood vessels and exsanguination. Next, the chickens were subjected to burning (semi-burning at a temperature of $50-52{ }^{\circ} \mathrm{C}$ for $90-180 \mathrm{~s}$ ) and the feathers were removed. The edible parts (liver, heart, stomach) were separated and weighted. The carcasses were cooled at a temperature below $4{ }^{\circ} \mathrm{C}$ for $24 \mathrm{~h}$ and subjected to a simplified slaughter analysis, which consisted of sampling and weighing pectoral and leg muscles, abdominal fat, as well as femurs and tibias. Measurements of both parts of the carcass were used for determination of their percentage proportion in the body weight. In turn, the femurs and tibias used for further analysis were collected from the right side of the carcass. 
Table 2. Nutrient contents in $1 \mathrm{~kg}$ of lucerne protein concentrate (LPC) and soyabean meal, dry matter basis

\begin{tabular}{lcc}
\hline Nutrients & LPC $^{1}$ & ${\text { Soyabean } \text { meal }^{2}}$ \\
\hline Crude protein, g & 552.1 & 474.0 \\
Histidine, g & 12.1 & 12.2 \\
Isoleucine, g & 23.3 & 21.1 \\
Leucine, g & 44.9 & 35.5 \\
Lysine, g & 30.5 & 28.1 \\
Methionine, g & 10.0 & 6.4 \\
Phenyloalanine, g & 27.2 & 19.8 \\
Threonine, g & 22.2 & 18.3 \\
Tryptophan, g & 11.8 & 6.2 \\
Valine, g & 29.8 & 22.4 \\
Tyrosine, g & 20.4 & 13.6 \\
Arginine, g & 29.4 & 34.4 \\
Crude fat, g & 108.6 & 10.0 \\
Crude fibre, g & 6.3 & 38.0 \\
Crude ash, g & 104.8 & 60.0 \\
Ca, g & 32.7 & 3.5 \\
P, g & 7.92 & 5.4 \\
K, g & 7.41 & 17.2 \\
Na, g & 0.13 & 0.4 \\
Mg, g & 1.45 & 2.4 \\
Fe, mg & 471.2 & 186.0 \\
Cu, mg & 10.51 & 15.8 \\
Zn, mg & 17.33 & 50.0 \\
Vitamin E, mg & 424.7 & 2.7 \\
Saturated fatty acids, g & 21.4 & $14.6^{3}$ \\
Monounsaturated fatty acids, g & 9.4 & $22.09^{3}$ \\
Polyunsaturated fatty acids, g & 56.6 & $56.46^{3}$ \\
\hline
\end{tabular}

${ }^{1}$ Grela et al. (2013); ${ }^{2}$ Poultry Feeding Standards according to Smulikowska and Rutkowski (2005); ${ }^{3}$ values according to NRC (2012)

\section{Chemical analysis}

The content of dry matter, crude ash, crude protein, ether extract and crude fibre in the feed samples was determined according to AOAC International (2000). Prior to the determination of the amino acid composition in the feed, the samples were hydrolysed in an aqueous solution ( $6 \mathrm{~N} \mathrm{HCI}+0.5 \%$ phenol at $110{ }^{\circ} \mathrm{C}$ for $24 \mathrm{~h}$ ) and analysed with ion-exchange chromatography in an AAA 400 amino acid analyzer (Ingos Ltd., Praha, Czech Republic) (Kwiecień et al., 2016). The contents of minerals (Ca, Mg, $\mathrm{Zn}, \mathrm{Cu}, \mathrm{Fe}$, except for phosphorus) in the feed and bones were determined in an ASA SOLAR 939 UNICAM(AASpectroeter Unicam, Shimadzu Corp., Tokyo, Japan) flame spectrophotometer (PN-EN ISO 6869:2002), whereas the phosphorus content were determined in an Spectronic Helios Delta 9423 UVD flame spectrophotometer (Wilmington, North Carolina, USA) (PN-ISO 6491: 2000). The content of minerals in the bone was calculated as their content in crude ash.

\section{Bone measurements}

After removal of soft tissues, the femur and tibia of the right leg were weighed and their length and circumference were measured (Figure 1). Next, each bone was wrapped in gauze saturated with an isotonic saline solution and stored at a temperature of $-25^{\circ} \mathrm{C}$ for further analyses. The data were used for calculation of the bone density index (BDI), which reveals changes in bone mineralization calculated as a ratio of the bone weight $(\mathrm{mg})$ to the length $(\mathrm{mm})$ (Ziaie et al., 2011).

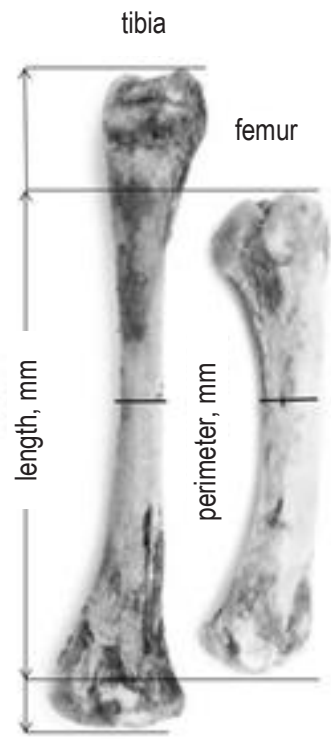

Figure 1. Sites of measurements of length and circumference of tibia and femur

\section{Analysis of mechanical and morphometric properties}

After a 3-h thawing at room temperature, the mechanical properties of bones were determined with a three-point bending test on the Zwick Z010 device (Zwick GmbH \& Co KG, Ulm-Einsingen, Germany) equipped with a measuring head with an operating range up to $10 \mathrm{kN}$ and a fixed speed of $10 \mathrm{~mm} \cdot \mathrm{min}^{-1}$. The device was coupled with a computer by means of TestXpert II 3,1 (Zwick GmbH \& Company KG, Ulm-Einsingen, Germany). The spacing between the supports was established at $40 \%$ of the total bone length. The mechanical properties of the bones were evaluated based on the values of their maximum elastic strength (Wy) and maximum ultimate strength (Wf) (Ferretti et al., 1993). The measurements allowed to determine the bone strength parameters, i.e. dy - deformation yield, Wf/A - bending point flexibility, Wy/dy load-to-deformation ratio and $\mathrm{E}$ - Young's modulus (Ferretti et al., 1993; Kwiecień et al., 2016). 


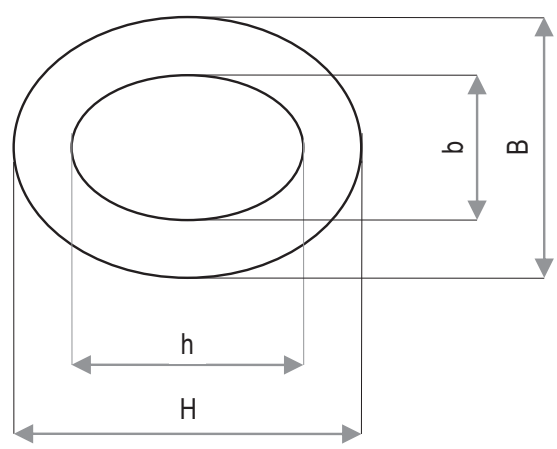

Figure 2. Sites of measurement of cross-sectional diameter of femur and tibia bone at fracture site, where: $\mathrm{H}$ - horizontal external diameter, h - horizontal internal diameter, B - vertical external diameter, $\mathrm{b}$ - vertical internal diameter

Measurements of the outer and inner horizontal and vertical diameters of the bone shaft cross-section at the fracture point (Figure 2) were used for determination of the geometric and cortical parameters of the femur and tibia shaft (Ferretti et al., 1993; Kwiecień et al., 2014). The measurement was performed with a calliper and the values obtained were used for calculation of geometrical parameters: Ix - second moment of inertia, A - cross-sectional area, MRWT - mean relative wall thickness, and cortical indices: cortical layer thickness, cortical surface, cortical index and cortical surface index (Kwiecień et al., 2014).

\section{Statistical analysis}

The obtained data were analysed with one-way analysis of variance ANOVA ( $\alpha=95 \% ; P \leq 0.05)$, and the mean values for the groups and the standard error of the mean (SEM) were calculated. The significance of differences between the mean values of the analysed traits was determined with the Duncan's post-hoc test in the Statistica 10.0 programme (StatSoft Inc., Tulsa, OK, USA).

\section{Results}

The LPC levels used in the broiler chicken diets exerted no significant effect on FCR, but they increased chicken body weight on day 21 by $9 \%(1.5 \%$ LPC) and $8.5 \%$ (3\% LPC) in comparison with group $\mathrm{C}$ (Table 3 ). In addition, there was a decline (by $50 \%$ ) in the mortality rates in the groups receiving diet with $1.5 \%$ and $3 \%$ of LPC $(P \leq 0.05)$. The addition of LPC from 1 to 21 day of rearing increased $(P \leq 0.05)$ feed intake by approx. 7\% (treatment $1.5 \%$ and $3 \%$ LPC) in comparison with treatment $\mathrm{C}$. In contrast, during the grower feeding period, a significant decrease in feed intake by $5.4 \%$ (treatment $1.5 \%$ LPC) and by $8.9 \%$ (treatment $3 \%$
Table 3. Effect of experimental treatments on growth performance of broiler chickens

\begin{tabular}{|c|c|c|c|c|c|}
\hline \multirow{3}{*}{ Indices } & \multicolumn{3}{|l|}{ Groups } & \multirow{3}{*}{ SEM } & \multirow{3}{*}{$P$-value } \\
\hline & \multirow{2}{*}{$\mathrm{C}^{1}$} & $1.5 \%$ & $3.0 \%$ & & \\
\hline & & \multicolumn{2}{|c|}{$\mathrm{LPC}^{2}$} & & \\
\hline \multicolumn{6}{|l|}{ Body weight, g } \\
\hline initial (1-day-old) & 37 & 38 & 39 & 0.352 & 0.235 \\
\hline day 10 & 227 & 236 & 235 & 2.833 & 0.421 \\
\hline 21 & $745^{b}$ & $812^{a}$ & $808^{a}$ & 11.21 & 0.020 \\
\hline 35 & 1661 & 1705 & 1677 & 17.41 & 0.585 \\
\hline 42 & 2078 & 2181 & 2164 & 31.30 & 0.367 \\
\hline \multicolumn{6}{|l|}{$F R^{3}, g \cdot g^{-1}$} \\
\hline days $1-21$ & 1.59 & 1.58 & 1.57 & 0.017 & 0.928 \\
\hline $22-35$ & 1.82 & 1.77 & 1.75 & 0.024 & 0.492 \\
\hline $36-42$ & 2.38 & 1.96 & 1.81 & 0.100 & 0.626 \\
\hline $1-42$ & 1.93 & 1.77 & 1.71 & 0.061 & 0.316 \\
\hline \multicolumn{6}{|l|}{$\mathrm{Fl}^{4}$, kg per bird } \\
\hline days $1-21$ & $1.13^{b}$ & $1.22^{\mathrm{a}}$ & $1.21^{\mathrm{a}}$ & 0.055 & 0.013 \\
\hline $22-35$ & $1.67^{\mathrm{a}}$ & $1.58^{b}$ & $1.52^{b}$ & 0.024 & 0.041 \\
\hline $36-42$ & $1.15^{\mathrm{a}}$ & $0.99^{\mathrm{ab}}$ & $0.91^{b}$ & 0.015 & 0.037 \\
\hline $1-42$ & $3.94^{\mathrm{a}}$ & $3.80^{\mathrm{b}}$ & $3.63^{c}$ & 0.084 & 0.002 \\
\hline \multicolumn{6}{|c|}{ Intake of nutrients } \\
\hline \multicolumn{6}{|c|}{$\mathrm{ME}, \mathrm{MJ} \cdot \mathrm{kg}^{-1} \cdot \mathrm{bird}^{-1}$} \\
\hline days $1-21$ & $14.31^{\mathrm{b}}$ & $15.26^{a}$ & $14.93^{\mathrm{ab}}$ & 0.022 & 0.041 \\
\hline $22-35$ & $21.74^{a}$ & $20.62^{\mathrm{ab}}$ & $19.76^{b}$ & 0.013 & 0.048 \\
\hline $36-42$ & $15.12^{\mathrm{a}}$ & $13.13^{b}$ & $11.88^{c}$ & 0.047 & 0.033 \\
\hline \multicolumn{6}{|l|}{ lysine, \% per bird } \\
\hline days $1-21$ & $1.46^{b}$ & $1.55^{\mathrm{a}}$ & $1.51^{\mathrm{ab}}$ & 0.022 & 0.011 \\
\hline $22-35$ & $1.84^{\mathrm{a}}$ & $1.75^{b}$ & $1.66^{\mathrm{c}}$ & 0.043 & 0.003 \\
\hline $36-42$ & $1.21^{\mathrm{a}}$ & $1.06^{\mathrm{ab}}$ & $0.94^{b}$ & 0.012 & 0.022 \\
\hline \multicolumn{6}{|c|}{ methionine, \% per bird } \\
\hline days $1-21$ & 0.75 & 0.72 & 0.71 & 0.035 & 0.117 \\
\hline $22-35$ & 0.82 & 0.79 & 0.75 & 0.018 & 0.068 \\
\hline $36-42$ & $0.53^{\mathrm{a}}$ & $0.47^{\mathrm{ab}}$ & $0.43^{b}$ & 0.037 & 0.044 \\
\hline Mortality, \% & $8.00^{\mathrm{a}}$ & $4.00^{\mathrm{b}}$ & $4.00^{\mathrm{b}}$ & 0.252 & 0.031 \\
\hline
\end{tabular}

LPC) was observed as compared with treatment C. During the finisher feeding and from 1 to 42 day of rearing, the lowest feed intake was found in the group with $3 \%$ addition of LPC, compared to treatment C (Table 3).

The $3 \%$ addition of LPC contributed to a $13.2 \%$ increase in the chilled carcass weight and a $2.98 \%$ increase in the slaughter yield in comparison with group $\mathrm{C}$, which received soyabean meal (Table 4). Irrespective of the amount of LPC added, there was an increase in the liver weight (by $23.5 \%$ and $52.8 \%$ ) and its proportion in the body weight (by 31.1 and $40.4 \%$ ), as compared with group C (Table 4). 
Table 4. Carcass performance, internal organs, meat and bone yields

\begin{tabular}{|c|c|c|c|c|c|}
\hline \multirow{3}{*}{ Indices } & \multicolumn{3}{|c|}{ Groups } & \multirow{3}{*}{ SEM } & \multirow{3}{*}{$P$-value } \\
\hline & \multirow{2}{*}{$C^{1}$} & $1.5 \%$ & $3.0 \%$ & & \\
\hline & & \multicolumn{2}{|c|}{$\mathrm{LPC}^{2}$} & & \\
\hline Chilled carcass weight, $\mathrm{g}$ & $1359^{b}$ & $1498^{\mathrm{ab}} 1$ & $1538^{\mathrm{a}}$ & 31.94 & 0.049 \\
\hline $\begin{array}{l}\text { Dressing percent, } \\
\mathrm{g} \cdot 100 \mathrm{~g}^{-1} \text { body weight }\end{array}$ & $73.7^{b}$ & $75.4^{\mathrm{ab}}$ & $75.9^{a}$ & 0.377 & 0.040 \\
\hline \multicolumn{6}{|c|}{ Proportions, $\mathrm{g} \cdot 100 \mathrm{~g}^{-1}$ body weight } \\
\hline liver & $1.66^{c}$ & $2.01^{b}$ & $2.33^{\mathrm{a}}$ & 0.083 & 0.001 \\
\hline abdominal fat & $1.67^{a}$ & $0.96^{b}$ & $0.81^{b}$ & 0.128 & 0.007 \\
\hline breast meat & 23.2 & 25.1 & 26.2 & 0.697 & 0.190 \\
\hline leg meat & 18.2 & 18.5 & 20.4 & 0.573 & 0.255 \\
\hline \multicolumn{6}{|c|}{ Weights of internal organs, $\mathrm{g}$} \\
\hline liver & $33.6^{c}$ & $43.2^{b}$ & $51.4^{\mathrm{a}}$ & 1.868 & $<0.001$ \\
\hline gizzard & 28.2 & 24.2 & 26.7 & 0.388 & 0.814 \\
\hline heart & 10.8 & 10.8 & 11.4 & 0.913 & 0.212 \\
\hline
\end{tabular}

${ }^{1} \mathrm{C}$ - control; ${ }^{2} \mathrm{LPC}$ - lucerne protein concentrate; SEM - standard error of the means; abc - mean values within each row with different superscripts are significantly different at $P \leq 0.05$

Table 5. Physical and morphometric parameters of chicken bones

\begin{tabular}{lll}
\hline & \multicolumn{2}{c}{ Groups } \\
\cline { 2 - 3 } Indices & \multicolumn{1}{c}{$\frac{1.5 \% 3.0 \%}{\mathrm{LPC}^{2}}$} & SEM $P$-value
\end{tabular}

\begin{tabular}{|c|c|c|c|c|c|}
\hline $\begin{array}{l}\text { Physical features } \\
\text { femur }\end{array}$ & & & & & \\
\hline $\begin{array}{c}\text { weight, } \mathrm{g} \cdot 100 \mathrm{~g}^{-1} \\
\text { of body weight }\end{array}$ & 0.68 & 0.73 & 0.74 & 0.020 & 0.419 \\
\hline length, mm & $67^{c}$ & $75^{\mathrm{a}}$ & $71^{\mathrm{bc}}$ & 1.006 & 0.001 \\
\hline perimeter, $\mathrm{mm}$ & $29^{b}$ & $33^{a}$ & $32^{\mathrm{a}}$ & 0.586 & 0.004 \\
\hline tibia & & & & & \\
\hline $\begin{array}{l}\text { weight, } \mathrm{g} \cdot 100 \mathrm{~g}^{-1} \\
\text { of body weight }\end{array}$ & 1.06 & 1.11 & 1.07 & 0.029 & 0.788 \\
\hline length, mm & $85^{b}$ & $96^{\mathrm{a}}$ & $97^{a}$ & 1.683 & 0.003 \\
\hline perimeter, mm & 30 & 31 & 32 & 0.504 & 0.158 \\
\hline $\begin{array}{l}\text { Geometrical characteristics of b } \\
\text { femur }\end{array}$ & bone & & & & \\
\hline $\mathrm{Ix}^{3}, \mathrm{~mm}^{4}$ & $130.2^{b}$ & $136.8^{a}$ & $137.2^{\mathrm{a}}$ & 6.167 & 0.029 \\
\hline $\mathrm{A}^{4}, \mathrm{~mm}^{2}$ & 20.2 & 20.5 & 20.8 & 0.524 & 0.630 \\
\hline MRWT $^{5}$ & $0.24^{b}$ & b $0.26^{a}$ & $0.26^{\mathrm{a}}$ & 0.007 & 0.013 \\
\hline tibia & & & & & \\
\hline $\mathrm{Ix}, \mathrm{mm}^{4}$ & $119.0^{\mathrm{b}}$ & $125.1^{\mathrm{a}}$ & $125.7^{\mathrm{a}}$ & 5.702 & 0.036 \\
\hline $\mathrm{A}, \mathrm{mm}^{2}$ & 22.1 & 22.5 & 23.2 & 0.514 & 0.430 \\
\hline $\mathrm{MRWT}^{4}$ & $0.32^{b}$ & b $0.34^{a}$ & $0.35^{a}$ & 0.008 & 0.032 \\
\hline $\begin{array}{l}\text { Features of cortical bone } \\
\text { femur }\end{array}$ & & & & & \\
\hline cortical layer thickness, mm & 1.69 & 1.73 & 1.84 & 0.071 & 0.486 \\
\hline cortical surface, $\mathrm{mm}^{2}$ & 25.6 & 25.6 & 26.6 & 0.525 & 0.759 \\
\hline cortical index, \% & 8.22 & 8.24 & 8.23 & 0.173 & 0.791 \\
\hline $\begin{array}{l}\text { cortical surface index, } \% \\
\text { tibia }\end{array}$ & 82.0 & 82.3 & 82.5 & 2.966 & 0.891 \\
\hline cortical layer thickness, mm & 2.21 & 2.25 & 2.36 & 0.051 & 0.386 \\
\hline cortical surface, $\mathrm{mm}^{2}$ & 34.2 & 34.2 & 35.2 & 0.625 & 0.655 \\
\hline cortical index, \% & 8.56 & 8.58 & 8.57 & 0.163 & 0.893 \\
\hline cortical surface index, $\%$ & 72.5 & 72.7 & 73.0 & 3.003 & 0.792 \\
\hline $\begin{array}{l}{ }^{1} \mathrm{C} \text { - control; }{ }^{2} \mathrm{LPC} \text { - lucerne } \\
\text { ment of inertia; }{ }^{4} \mathrm{~A} \text { - cross-se } \\
\text { wall thickness; SEM - standar } \\
\text { within each row with different } \\
\text { at } P \leq 0.05\end{array}$ & $\begin{array}{l}\text { protein } \\
\text { ectional } \\
\text { ird error } \\
\text { t supers }\end{array}$ & scripts ar & rate; ${ }^{3} \mathrm{Ix}$ & $x-\sec 0$ & $\begin{array}{l}\text { ond mo- } \\
\text { relative } \\
\text { v values } \\
\text { differen }\end{array}$ \\
\hline
\end{tabular}

Additionally, after feeding of the $1.5 \%$ and $3 \%$ doses of LPC, a reduced $(P \leq 0.05)$ proportion (by $42.5 \%$ and $51.5 \%$, respectively) of abdominal fat was noted (Table 4).

The addition of $1.5 \%$ of LPC increased $(P \leq 0.05)$ the femur length in comparison with group $\mathrm{C}$ and chickens fed diet supplemented with 3\% of LPC (Table 5). Irrespective of the dose, the addition of LPC increased the circumference of the tibia (on average by $12.1 \%$ ). In turn, the greatest lengths of tibia were found in the LPC-supplemented groups (Table 5).

Regardless of the supplementation level, the LPC additive did not exert an effect on the geometric and cortical bone parameters. However, it significantly increased the Ix value of the femur (on average by $5.25 \%$ ) and tibia (on average by $5.37 \%$ ) as well as the mean relative wall thickness (MRWT) in both bones (by $8.33 \%$ in the femur and by $6.25 \%$ in the tibia) as compared with the parameters in the control group (Table 5).

Irrespective of the LPC amount, there was an increase $(P \leq 0.05)$ in the femoral mechanical properties (Wy, Wf, Wy/dy, BDI) by $20.1 \%, 12.4 \%$, $16.2 \%$ and $12.2 \%$, respectively (Table 6). A similar trend (with the exception of Wf) was observed for the tibia. At the $3 \%$ addition of LPC, the value of

Table 6. Strength parameters of chicken bones

\begin{tabular}{|c|c|c|c|c|c|}
\hline \multirow{3}{*}{ Indices } & \multicolumn{3}{|c|}{ Groups } & \multirow{3}{*}{ SEM } & \multirow{3}{*}{$P$-value } \\
\hline & \multirow{2}{*}{$\mathrm{C}^{1}$} & $1.5 \%$ & $3.0 \%$ & & \\
\hline & & \multicolumn{2}{|c|}{$\mathrm{LPC}^{2}$} & & \\
\hline \multicolumn{6}{|l|}{ Femur } \\
\hline $\mathrm{Wy}^{3}, \mathrm{~N} \cdot \mathrm{mm}$ & $135.5^{\mathrm{b}}$ & $159.9^{a}$ & $165.4^{\mathrm{a}}$ & 5.372 & 0.013 \\
\hline $\mathrm{dy}^{4}, \mathrm{~mm}$ & 1.88 & 1.89 & 1.97 & 0.125 & 0.092 \\
\hline $\mathrm{Wf}^{5}, \mathrm{~N} \cdot \mathrm{mm}$ & $215.4^{b}$ & $239.6^{a}$ & $244.7^{a}$ & 7.433 & 0.043 \\
\hline Wy $/ \mathrm{dy}^{6} \mathrm{~N} \cdot \mathrm{mm} \cdot \mathrm{mm}^{-1}$ & $72.1^{b}$ & $84.2^{\mathrm{a}}$ & $83.4^{\mathrm{a}}$ & 5.306 & 0.050 \\
\hline $\mathrm{Wf} / \mathrm{A}^{7}, \mathrm{~N} \cdot \mathrm{mm} \cdot \mathrm{mm}^{-2}$ & 10.6 & 11.6 & 11.1 & 0.551 & 0.093 \\
\hline $\mathrm{E}^{8}, \mathrm{~N} \cdot \mathrm{m}^{-2}$ & 1.45 & 1.49 & 1.52 & 3.937 & 0.064 \\
\hline $\mathrm{BDl}^{9}, \mathrm{mg} \cdot \mathrm{mm}^{-1}$ & $199.7^{b}$ & $218.7^{a}$ & $229.3^{a}$ & 5.460 & 0.022 \\
\hline \multicolumn{6}{|l|}{ Tibia } \\
\hline $\mathrm{Wy}, \mathrm{N} \cdot \mathrm{mm}$ & $142.2^{b}$ & $167.8^{\mathrm{a}}$ & $175.7^{a}$ & 5.288 & 0.011 \\
\hline dy, mm & 1.19 & 1.20 & 1.22 & 0.115 & 0.072 \\
\hline $\mathrm{Wf}, \mathrm{N} \cdot \mathrm{mm}$ & $243.5^{b}$ & $267.8^{\mathrm{ab}}$ & $283.6^{a}$ & 7.672 & 0.045 \\
\hline Wy/dy, $\mathrm{N} \cdot \mathrm{mm} \cdot \mathrm{mm}^{-1}$ & $119.2^{b}$ & $139.4^{\mathrm{a}}$ & $142.1^{\mathrm{a}}$ & 36.285 & 0.109 \\
\hline $\mathrm{Wf} / \mathrm{A}, \mathrm{N} \cdot \mathrm{mm} \cdot \mathrm{mm}^{-2}$ & 11.4 & 11.5 & 11.9 & 0.463 & 0.457 \\
\hline $\mathrm{E}, \mathrm{N} \mathrm{m}^{-2}$ & 2.43 & 2.51 & 2.55 & 0.259 & 0.026 \\
\hline $\mathrm{BDI}, \mathrm{mg} \cdot \mathrm{mm}^{-1}$ & $238.2^{b}$ & $253.4^{a}$ & $263.6^{a}$ & 5.041 & 0.038 \\
\hline
\end{tabular}

${ }^{1} \mathrm{C}$-control; ${ }^{2} \mathrm{LPC}$-lucerne protein concentrate; ${ }^{3} \mathrm{Wy}$-maximum elastic strength; ${ }^{4} \mathrm{dy}$ - yielding deformation; ${ }^{5} \mathrm{Wf}$ - maximum ultimate strength; ${ }^{6} \mathrm{Wy} / \mathrm{dy}$ - load-to-deformation ratio; ${ }^{7} \mathrm{Wf} / \mathrm{A}$ - bending point resistance; ${ }^{8} \mathrm{E}$ - Young's modulus; ${ }^{9} \mathrm{BDI}$ - bone density index; SEM - standard error of the means; ${ }^{a b}$ - mean values within each row with different superscripts are significantly different at $P \leq 0.05$ 
Wf increased significantly in comparison with that noted in group C (Table 6).

The LPC levels used in the experiment resulted in a significant increase in the $\mathrm{Ca}$ and $\mathrm{Zn}$ content in both the femur and tibia (Table 7).

Table 7. The mineral composition of crude ash of chicken bones

\begin{tabular}{|c|c|c|c|c|c|}
\hline \multirow{3}{*}{ Indices } & \multicolumn{3}{|c|}{ Groups } & \multirow{3}{*}{ SEM } & \multirow{3}{*}{$P$-value } \\
\hline & \multirow{2}{*}{$\mathrm{C}^{1}$} & $1.5 \%$ & $3.0 \%$ & & \\
\hline & & \multicolumn{2}{|c|}{$\mathrm{LPC}^{2}$} & & \\
\hline \multicolumn{6}{|l|}{ Femur } \\
\hline crude ash, \% & 17.8 & 18.4 & 17.9 & 0.233 & 0.539 \\
\hline $\mathrm{Ca}, \mathrm{g} \cdot \mathrm{kg}^{-1}$ & $266.6^{b}$ & $277.9^{a}$ & $274.8^{a}$ & 1.742 & 0.019 \\
\hline$P, g \cdot \mathrm{kg}^{-1}$ & 184.0 & 188.5 & 184.9 & 3.626 & 0.284 \\
\hline $\mathrm{Mg}, \mathrm{g} \cdot \mathrm{kg}^{-1}$ & 8.82 & 8.96 & 8.83 & 0.075 & 0.605 \\
\hline $\mathrm{Zn}, \mathrm{mg} \cdot \mathrm{kg}^{-1}$ & $425.4^{b}$ & $518.6^{a}$ & $534.7^{\mathrm{a}}$ & 17.043 & 0.015 \\
\hline $\mathrm{Cu}, \mathrm{mg} \cdot \mathrm{kg}^{-1}$ & 4.48 & 4.17 & 3.91 & 0.149 & 0.352 \\
\hline $\mathrm{Fe}, \mathrm{mg} \cdot \mathrm{kg}^{-1}$ & 399.1 & 411.0 & 355.4 & 17.248 & 0.410 \\
\hline \multicolumn{6}{|l|}{ Tibia } \\
\hline crude ash, \% & 25.0 & 25.6 & 25.2 & 2.997 & 0.519 \\
\hline $\mathrm{Ca}, \mathrm{g} \cdot \mathrm{kg}^{-1}$ & $279.1^{b}$ & $290.4^{a}$ & $287.3^{\mathrm{a}}$ & 13.670 & 0.026 \\
\hline $\mathrm{P}, \mathrm{g} \cdot \mathrm{kg}^{-1}$ & 174.6 & 179.1 & 175.4 & 1.220 & 0.261 \\
\hline $\mathrm{Mg}, \mathrm{g} \cdot \mathrm{kg}^{-1}$ & 8.03 & 8.17 & 8.04 & 0.065 & 0.625 \\
\hline $\mathrm{Zn}, \mathrm{mg} \cdot \mathrm{kg}^{-1}$ & $446.7^{b}$ & $539.9^{a}$ & $556.0^{\mathrm{a}}$ & 17.243 & 0.023 \\
\hline $\mathrm{Cu}, \mathrm{mg} \cdot \mathrm{kg}^{-1}$ & 5.69 & 5.38 & 5.12 & 0.159 & 0.252 \\
\hline $\mathrm{Fe}, \mathrm{mg} \cdot \mathrm{kg}^{-1}$ & 423.2 & 435.1 & 379.5 & 17.448 & 0.310 \\
\hline
\end{tabular}

${ }^{1} \mathrm{C}$ - control; ${ }^{2} \mathrm{LPC}$ - lucerne protein concentrate; SEM - standard error of the means; ${ }^{a b}$ - mean values within each row with different superscripts are significantly different at $P \leq 0.05$

\section{Discussion}

In recent years, there has been growing interest in phytobiotics, i.e. feed additives providing a variety of biologically active compounds that improve digestion and utilization of feed nutrients (Grela et al., 2013). Intensive genetic selection resulting in higher yield performance in birds requires proper nutrient balance. LPC is a phytobiotic that can increase body and muscle weight and, simultaneously, substantially reduce the incidence of chicken disease and increase the feed conversion ratio (Jiang et al., 2012). It is characterized by a high content (over 50\%) and biological value of protein; it is also a source of many minerals and vitamins, as well as flavonoids, phenolic acids, xanthophylls and carotenoids (Grela et al., 2013). The present investigations have shown a positive trend towards an increase in the body weight of chickens fed the LPC-supplemented diets, regardless of the used dose. Furthermore, chickens receiving diet with LPC addition exhibited a tendency towards lower feed intake and better feed conversion ratio. Phytoestrogens contained in the LPC have an affinity for oestrogen receptors and are capable of activation thereof. Since their action is similar to that of hormones, they may have an impact on the chickens' growth (Robards and Antolovich, 1997).

The most important indicators of the overall performance of modern broiler chicken lines are the growth rates and carcass yield. Therefore, there are attempts at introduction and application of additives that are a good source of nutrients, primarily protein and improve production performance and quality of animal products, which can be applied as prophylaxis of some conditions, e.g., human malnutrition. In our research, we have observed an increase in the chicken slaughter yield and chilled carcass weight after addition of $3 \%$ of LPC. Additionally, a beneficial impact on the weight of pectoral muscles accompanied by reduced amounts of abdominal fat was noted regardless of the level of the LPC. Therefore, consumption of products derived from such chickens is safe even at a longer supplementation period, since the concentrate does not contain Aspergillus flavus toxins, pesticides or heavy metals, and its microbiology meets the food standards for humans (EFSA, 2009). Furthermore, the LPC exhibits predominance of polyunsaturated fatty acids, with a large proportion of n-3 fatty acids characterized by a favourable $n-6 / n-3$ fatty acid ratio (Grela et al., 2013).

Intensive growth of broiler chickens often leads to development of skeletal system disorders in roosters, which are characterized by a higher growth rate than that in female chickens. High body weight determined by pectoral and leg muscles and a high muscle-to-bone weight ratio can be as cause of deformities and fractures (Rao et al., 2003). Bone development, maturation and strength are also determined by genetic, nutritional and physiological factors. Oestrogens and androgens are indispensable for acquisition and maintenance of optimum bone mass; hence, hormonal disorders or loss of gonadal function lead to accelerated resorption and increased bone loss (Malcolm, 2002). Phytoestrogens, such as flavonoids, represented by genistein and biochanin A in lucerne, inhibit the formation of osteoclastic cells, i.e. osteoclasts, and stimulate the activity of osteogenic cells, i.e. osteoblasts (Branca, 2003). Furthermore, a stimulatory effect of isoflavones on the secretion of insulin-like growth factor I (IGF-I) has been reported. It directly stimulates in vitro collagen synthesis by osteoblasts and can mediate the effects of parathyroid hormone on bones (Arjmandi et al., 2003). In this study, the bones of the broilers after 
the rearing period were normally developed and had no signs of fractures, cracks or other damage. Upon the LPC treatment, there were no changes in the bone weight per $100 \mathrm{~g}$ body weight; in turn, a significant modifying effect of the LPC on the length of bones, which were the longest regardless of the additive dose, was only observed. Probably, the content of such compounds as phytosterols, flavonoids and glycosides in LPC can support and facilitate bone metabolism (Branca, 2003). Additionally, it has been found that the type of dietary fats plays a major role in bone metabolism. The n-6/n-3 fatty acid ratio in the diet has a substantial effect on the fatty acid composition and biosynthesis of prostaglandins, which regulate bone formation and resorption (Maggio et al., 2009). LPC is a source of linolenic acid $\left(\mathrm{C} 18: 3_{\mathrm{n}-3}\right)$. Consumption of long-chain n-3 polyunsaturated fatty acids (PUFA) determines the $n-6 / n-3$ ratio and the acid ratio in tissues, reduces prostaglandin $\mathrm{PGE}_{2}$ production, and enhances bone growth, probably by inhibition of the activity of osteoclasts and bone resorption (Lukas et al., 2011). However, the available results concerning the effect of fatty acids on bones are inconsistent, which may be associated with the differences in the studied n-3 PUFA (Korotkova et al., 2004) and the type of lipid-bound protein (Fernandes et al., 2003).

Bone mechanical strength is a result of architectural (geometrical and cortical) features, mineralization degree, as well as the maturity and quality of the bone building material (Ferretti et al., 1993). The A values of the analysed bones did not exhibit significant differences between the experimental groups and the control group, in comparison with the other geometric parameters of bone. Geometric parameters, in particular Ix, have a significant impact on the bone structure. The Ix values in the femur were higher after the LPC addition $(1.5 \%$ and $3 \%$ ). A similar trend was observed in the tibia, although the index had a higher value in the case of the femur. The MRWT values exhibited an opposite trend, i.e. higher values were noted for the tibia. Given the similar A values, the differences in the Ix and MRWT values are probably a result of the different values of the outer and inner diameters of the bone shaft. It can be assumed that the LPC addition significantly increased the cortical thickness (MRWT), which contributes to higher mechanical resistance to applied forces. Moreover, after application of the LPC, there was a beneficial trend towards an increase in the cortical layer thickness, which may be associated with the higher content of $\mathrm{Ca}$ and $\mathrm{P}$ in lucerne (Grela et al., 2013). Similarly, after addition of lucerne, Y1ld1z and Alpay (2008) observed an increase $(P \leq 0.05)$ in the cortical layer thickness in both femora and tibiae, compared with other groups.

Changes in mechanical parameters are a reflection of changes occurring in bones throughout the lifetime. Despite their considerable hardness, bones exhibit some plasticity and flexibility and respond to continuous or repeated action of deformation forces associated with loading and unloading by changes in the structure (Malcolm, 2002). The analysis of bone strength revealed that bones sampled from birds fed diets supplemented with LPC were characterized by higher flexibility and breaking strength. The application of LPC in this study improved the quality of tibiae and femora and their strength parameters, which was probably associated with enhanced $\mathrm{Ca}$ and $\mathrm{Zn}$ deposition in bones. The correlation between bone mechanical strength and its geometric properties and mineralization degree has been reported by Ferretti et al. (1993). Increased bone mineralization was indicated by the BDI index, which may be related to the presence of genistein in the LPC. It has a dual effect on bone mineral density: low doses of the phytoestrogen stimulate the parameter, while high doses cause reduction thereof. Additionally, coumestrol present in lucerne can inhibit resorption and stimulate mineralization of bone tissue (Vincent and Fitzpatrick, 2000). In the available literature there are no publications on the effect of lucerne preparations on bone parameters in broiler chickens; hence, comparison of the results with reports of other authors is practically impossible. Therefore, this report provides some theoretical and practical values.

The content of crude ash in chicken bones is a good indicator of increasing bone mineralization, but it turned out not to be dependent on the LPC addition in this study. Still, the levels of the LPC used in this experiment resulted in a significant increase in the $\mathrm{Ca}$ and $\mathrm{Zn}$ content both in the femora and tibiae. Thirty percent of the total $\mathrm{Zn}$ content in the organism is present in the bones; hence, this element is highly important for development of the skeletal system and physiological bone homeostasis (Seo et al., 2010). Zn deficiency usually results from limited absorption from food, which can cause disorders in the development of the skeletal system. Increased $\mathrm{Ca}$ and $\mathrm{Zn}$ content in bones can reflect absorption enhancement by lucerne and, consequently, indicate normal development, enhanced growth, and improved strength of bones. 


\section{Conclusions}

The results of this study indicate that the addition of $1.5 \%$ or $3.0 \%$ of lucerne protein-xanthophyll concentrate (LPC) to the feed mixtures contributed to normal growth of chickens, reduced the mortality and increased muscle weight. Probably, the bioactive compounds present in LPC increased the bone mechanical strength related to the elevated geometric parameters and cortical layer thickness. Additionally, the bones were characterized by higher flexibility and by improved breaking strength. The higher $\mathrm{Ca}$ and $\mathrm{Zn}$ contents and bone density index values indicated normal bone mineralization.

\section{References}

AOAC International, 2000. Official Methods of Analysis of AOAC International. $17^{\text {th }}$ Edition. Gaithersburg, MD (USA)

Arjmandi B.H., Khalil D.A., Smith B.J., Lucas E.A., Juma S., Payton M.E., Wild R.A., 2003. Soy protein has a greater effect on bone in postmenopausal women not on hormone replacement therapy, as evidenced by reducing bone resorption and urinary calcium excretion. J. Clin. Endocrinol. Metab. 88, 1048-1054, https://doi.org/10.1210/jc.2002-020849

Branca F., 2003. Dietary phyto-oestrogens and bone health. Proc. Nutr. Soc. 62, 877-887, https://doi.org/10.1079/PNS2003309

Dibner J.J., Richards J.D., Kitchell M.L., Quiroz M.A., 2007. Metabolic challenges and early bone development. J. Appl. Poult. Res. 16, 126-137, https://doi.org/10.1093/japr/16.1.126

Dong X.F., Gao W.W., Tong J.M., Jia H.Q., Sa R.N., Zhang Q., 2007. Effect of polysavone (alfalfa extract) on abdominal fat deposition and immunity in broiler chickens. Poult. Sci. 86, 1955-1959, https://doi.org/10.1093/ps/86.9.1955

EFSA, 2009. Opinion on the safety of 'Alfalfa protein concentrate' as food. EFSA J. 997, 1-19

Fernandes G., Lawrence R., Sun D., 2003. Protective role of n-3 lipids and soy protein in osteoporosis. Prostaglandins Leukot. Essent. Fatty Acids 68, 361-372, https://doi.org/10.1016/S09523278(03)00060-7

Ferretti J.L., Capozza R.F., Mondelo N., Zanchetta J.R., 1993. Interrelationships between densitometric, geometric and mechanical properties of rat femora: inferences concerning mechanical regulation of bone modelling. J. Bone Miner. Res. 8, 1395-1399, https://doi.org/10.1002/jbmr.5650081113

Grela E.R., Ognik K., Czech A., Matras J., 2014. Quality assessment of eggs from laying hens fed a mixture with lucerne protein concentrate. J. Anim. Feed Sci. 23, 236-243, https://doi. org/10.22358/jafs/65686/2014

Grela E.R., Pietrzak K., Kowalczuk-Vasilev E., Klebaniuk R., Borucka B., 2013. Analysis of chemical composition of protein-xanthophyll concentrate (in Polish). Przem. Chem. 92, 1484-1488

Güçlü K.B., İşcan K.M., Uyanik F., Eren M., Can Ağca A., 2004. Effect of alfalfa meal in diets of laying quails on performance, egg quality and some serum parameters. Arch. Anim. Nutr. 58, 255-263, https://doi.org/10.1080/00039420410001701350

Hammershøj M., Steenfeldt S., 2005. Effects of blue lupin (Lupinus angustifolius) in organic layer diets and supplementation with foraging material on egg production and some egg quality parameters. Poult. Sci. 84, 723-733, https://doi.org/10.1093/ ps/84.5.723
Janssen W.M.M.A., 1989. European Table of Energy Values for Poultry Feedstuffs. $3^{\text {rd }}$ Edition. Subcommittee Energy of the Working Group no. 2 Nutrition of the European Federation of Branches of the World's Poultry Science Association. Beekbergen (the Netherlands)

Jiang J.F., Song X.M., Huang X., Wu J.L., Zhou W.D., Zheng H.C., Jiang Y.Q., 2012. Effects of alfalfa meal on carcase quality and fat metabolism of Muscovy ducks. Br. Poult. Sci. 53, 681-688, https://doi.org/10.1080/00071668.2012.731493

Karwowska M., Stadnik J., Dolatowski Z.J., Grela E.R., 2010. Effect of protein-xanthophylls (PX) concentrate of alfalfa supplementation on physico-chemical properties of turkey breast and thigh muscles during ageing. Meat Sci. $86,486-490$, https://doi. org/10.1016/j.meatsci.2010.05.040

Korotkova M., Ohlsson C., Hanson L.Å., Strandvik B., 2004. Dietary $n-6: n-3$ fatty acid ratio in the perinatal period affects bone parameters in adult female rats. Br. J. Nutr. 92, 643-648, https:// doi.org/10.1079/BJN20041252

Krauze M., Grela E.R., 2010. Effects of an alfalfa concentrate in turkey diets on performance and some blood parameters. Arch. Geflügelk. 74, 226-232

Kwiecień M., Winiarska-Mieczan A., Milczarek A., Tomaszewska E., Matras J., 2016. Effects of zinc glycine chelate on growth performance, carcass characteristics, bone quality, and mineral content in bone of broiler chicken. Livest. Sci. 191, 43-50, https://doi.org/10.1016/j.livsci.2016.07.005

Kwiecień M., Winiarska-Mieczan A., Zawiślak K., Sroka S., 2014. Effect of copper glycinate chelate on biomechanical, morphometric and chemical properties of chicken femur. Ann. Anim. Sci. 14, 127-139, https://doi.org/10.2478/aoas-2013-0085

Laudadio V., Ceci E., Lastella N.M.B., Introna M., Tufarelli V., 2014. Low-fiber alfalfa (Medicago sativa L.) meal in the laying hen diet: Effects on productive traits and egg quality. Poult. Sci. 93, 1868-1874, https://doi.org/10.3382/ps.2013-03831

Lukas R., Gigliotti J.C., Smith B.J., Altman S., Tou J.C., 2011. Consumption of different sources of omega-3 polyunsaturated fatty acids by growing female rats affects long bone mass and microarchitecture. Bone 49, 455-462, https://doi. org/10.1016/j.bone.2011.05.029

Maggio M., Artoni A., Lauretani F., Borghi L., Nouvenne A., Valenti G., Ceda G.P., 2009. The impact of omega-3 fatty acids on osteoporosis. Curr. Pharm. Design 15, 4157-4164, https://doi. org/10.2174/138161209789909728

Malcolm A.J., 2002. Metabolic bone disease. Curr. Diagn. Pathol. 8, 19-25, https://doi.org/10.1054/cdip.2001.0091

Mourão J.L., Ponte P.I.P., Prates J.A.M., Centeno M.S.J., Ferreira L.M.A., Soares M.A.C., Fontes C.M.G.A., 2006. Use of $\beta$-glucanases and $\beta-1,4$-xylanases to supplement diets containing alfalfa and rye for laying hens: Effects on bird performance and egg quality. J. Appl. Poult. Res. 15, 256-265, https://doi. org/10.1093/japr/15.2.256

NRC, 1994. Nutrient Requirements of Poultry. $9^{\text {th }}$ revised Edition. National Academy Press. Washington, DC (USA), https://doi. org/10.17226/2114

NRC, 2012. Nutrient Requirements of Swine. $11^{\text {th }}$ Edition. National Academy Press. Washington, DC (USA), https://doi. org/10.17226/13298

PN-EN ISO 6869: 2002. Animal feeding stuffs - Determination of the contents of calcium, copper, iron, magnesium, manganese, potassium, sodium and zinc - Method using atomic absorption spectrometry (in Polish)

PN-ISO 6491: 2000. Animal feeding stuffs - Determination of the phosphorus content - Spectrometric method (in Polish) 
Rao R.S.V., Raju M.V.L.N., Sharma R.P., Nagalakshmi D., Reddy M.R., 2003. Lameness in chickens: alleviation by dietary manipulation. Poult. Int. 42, 56-61

Robards K., Antolovich M., 1997. Analytical chemistry of fruit bioflavonoids. A review. Analyst 122, 11R-34R, https://doi. org/10.1039/a606499j

Seo H.-J., Cho Y.-E., Kim T., Shin H.-I., Kwun I.-S., 2010. Zinc may increase bone formation through stimulating cell proliferation, alkaline phosphatase activity and collagen synthesis in osteoblastic MC3T3-E1 cells. Nutr. Res. Pract. 4, 356-361, https:// doi.org/10.4162/nrp.2010.4.5.356

Shen C.-L., Yeh J.K., Rasty J., Li Y., Watkins B.A., 2006. Protective effect of dietary long-chain n-3 polyunsaturated fatty acids on bone loss in gonad-intact middle-aged male rats. $\mathrm{Br}$. J. Nutr. 95, 462-468, https://doi.org/10.1079/BJN20051664
Smulikowska S., Rutkowski A. (Editors), 2005. Recommended Allowances and Nutritive Value of Feedstuffs. Poultry Feeding Standards (in Polish). $4^{\text {th }}$ Edition. The Kielanowski Institute of Animal Physiology and Nutrition, Polish Academy of Sciences, Jabłonna (Poland)

Vincent A., Fitzpatrick L.A., 2000. Soy isoflavones: Are they useful in menopause? Mayo Clin. Proc. 75, 1174-1184, https://doi. org/10.4065/75.11.1174

Yıldız H., Alpay F., 2008. The effects of different moulting diets on bone characteristics and reproductive tracts in commercial brown egg laying hens. Vet. Arh. 78, 227-234

Ziaie H., Bashtani M., Karimi Torshizi M.A., Naeeimipour H., Farhangfar H., Zeinali A., 2011. Effect of antibiotic and its alternatives on morphometric characteristics, mineral content and bone strength of tibia in Ross broiler chickens. Glob. Vet. 7 , 315-322 